\title{
Analisis Pemanfaatan Metode Markerless User Defined Target Pada Augmented Reality Sholat Shubuh
}

\author{
Randy Gusman ${ }^{1}$, Meyti Eka Apriyani ${ }^{2}$ \\ ${ }^{1,2}$ Jurusan Teknik Informatika, Program Studi Teknik Multimedia dan Jaringan, Politeknik Negeri Batam \\ ${ }^{1,2} \mathrm{Jl}$. Ahmad Yani, Parkway Batam Centre 29461, Batam, Indonesia \\ Email korespondensi : randygusman04@gmail.com, meyti24@gmail.com
}

Dikirim 15 Maret 2016, Diperbaiki 22 April 2016, Diterima 26 April 2016

\begin{abstract}
Abstrak - Aplikasi augmented reality pada umumnya menggunakan marker khusus untuk menjalankan aplikasi (marker based). Penggunaan marker tersebut membuat aplikasi menjadi ketergantungan, karena aplikasi hanya akan dapat dijalankan jika marker tersedia. Penelitian ini bertujuan untuk menampilkan objek 3 dimensi pada lingkungan augmented reality tanpa menggunakan marker khusus pada perangkat android. Aplikasi dibuat menggunakan metode markerless user defined target dan melakukan pengujian tentang pemanfaatan metode tersebut menggunakan parameter seperti kontras warna permukaan datar, bentuk objek, jarak, cahaya dan sudut kamera pada saat tracking. Hasil dari penelitian didapatkan bahwa seluruh benda dapat digunakan pada metode markerless user defined target. Benda terbaik untuk menampilkan objek 3 dimensi adalah permukaan datar kertas dengan kontras bagus, sudut tracking $45^{\circ}$, menggunakan sumber cahaya terang yang tidak tegak lurus dengan marker dan jarak ideal $15 \mathrm{~cm}$ sampai $25 \mathrm{~cm}$.
\end{abstract}

Kata kunci - Augmented Reality, Markerless, User Defined Target, Android.

Abstract - Augmented reality applications generally use special marker for executing the applications (markerbased). The use of this special marker makes the application becomes dependency, because the application will only can be executed if the marker is available. This research aims to show 3 dimensional object in augmented reality environment without using a special marker on android devices. Applications are made using markerless user defined target method and conduct testing on the use of the method using some objects in daily life with some parameters, such as contrast on the flat surfaces of paper, shapes, distance, lighting and camera angle tracking. Result of the research showed that all objects can be used on markerless user defined target's method. The best object for displaying a three-dimensional object is a flat surface of paper with good contrast, camera angle tracking $45^{\circ}$, using a bright light source which is not prependicular to the marker and the ideal distance is $15 \mathrm{~cm}$ to $25 \mathrm{~cm}$.

Keywords - Augmented Reality, Markerless, User Defined Target, Android.

\section{PENDAHULUAN}

Augmented reality adalah variasi dari virtual reality. Teknologi virtual reality sepenuhnya memasukkan pengguna pada lingkungan virtual, sehingga pengguna tidak dapat melihat dunia nyata di sekelilingnya. Sebaliknya, augmented reality yang dalam bahasa Indonesia disebut realitas tertambah adalah teknologi yang menggabungkan benda maya dua dimensi dan ataupun tiga dimensi ke dalam sebuah lingkungan nyata tiga dimensi lalu memproyeksikan benda-benda maya tersebut dalam waktu nyata. Augmented reality memungkinkan pengguna untuk melihat benda virtual yang menyatu dengan dunia nyata [1].

Augmented reality dapat dikategorikan menjadi dua berdasarkan ada atau tidaknya penanda (marker) yaitu marker based augmented reality dan markerless augmented reality. Marker merupakan sebuah gambar dengan pola unik yang dapat diambil dengan kamera serta dapat dikenali oleh aplikasi augmented reality [2]. Aplikasi augmented reality pada umumnya menggunakan marker khusus atau buku sebagai media dari sekumpulan marker (marker based augmented reality). Marker khusus tersebut mengakibatkan aplikasi augmented reality menjadi ketergantungan karena aplikasi hanya dapat dijalankan jika marker tersedia. Markerless augmented reality akan sangat praktis jika dapat diterapkan pada augmented reality menggunakan smartphone android karena aplikasi dapat dijalankan dimanapun tanpa perlu mencetak marker [3].

Salah satu penerapan dari markerless augmented reality adalah menggunakan user defined target. User defined target merupakan marker yang terbentuk pada saat kamera men-scan suatu target yang dipilih oleh user. Penggunaan user defined target membuat aplikasi dapat dijalankan setiap saat dan dimana saja 
karena tidak harus menggunakan suatu marker khusus pada saat menjalankannya [4].

Metode markerless user defined target diimplementasikan pada augmented reality sholat shubuh dan dilakukan pengujian terhadap pemanfaatannya dengan harapan supaya dapat mempermudah user dalam menggunakan aplikasi, sekaligus sebagai media pembelajaran ibadah sholat shubuh bagi umat muslim khususnya.

\section{A. Sholat Shubuh}

Sholat shubuh merupakan sholat wajib bagi umat Islam yang dikerjakan pada pagi hari saat fajar tiba. Karenanya dalam bahasa Arab, sholat shubuh lebih sering disebut sholat fajar. Ikrimah meriwayatkan [5], bahwa sholat shubuh merupakan sholat yang paling banyak ditinggalkan orang. Simulasi gerakan sholat shubuh dibuat kedalam bentuk augmented reality dengan harapan agar dapat menjadi media pembelajaran baru yang dapat dipelajari kembali dan dapat diamalkan oleh umat Muslim dalam kehidupan sehari-hari.

\section{B. Augmented Reality}

Secara umum prinsip augmented reality masih sama dengan virtual reality yaitu bersifat interaktif, immersion (membenamkan / memasukan), realtime dan objek virtual biasanya berbentuk tiga dimensi. Virtual reality menggabungkan objek nyata (user) kedalam lingkungan virtual sedangkan augmented reality menggabungkan objek virtual pada lingkungan nyata [1].

Teknologi augmented reality telah dikembangkan dalam berbagai hal, dalam pemanfaatanya teknologi ini dapat digunakan pada augmented reality interactive games, augmented reality presentation, augmented reality event, augmented reality high tech environment, augmented reality website, augmented reality promotion dan augmented reality for education.

\section{Markerless User Defined Target}

Markerless merupakan sebuah metode pelacakan augmented reality menggunakan objek di dunia nyata sebagai marker atau tanpa menggunakan marker khusus. Augmented reality dengan teknik tanpa penanda ini menggunakan teknik pelacakan secara alami (natural feature) bukan pengenalan penanda (fiducial marker). Teknik ini menggunakan prinsip deteksi tepi, deteksi sudut dan tekstur dari gambar atau objek [2].

User defined target merupakan salah satu pemanfaatan dari markerless augmented reality. User defined target adalah image target (gambar penanda) yang terbuat pada saat runtime dari frame kamera yang dipilih oleh user. Atau dengan kata lain, user defined target merupakan marker yang terbentuk pada saat kamera memindai suatu target [4].

\section{Parameter Analisis}

Parameter yang digunakan pada penelitian ini dibagi menjadi dua yaitu parameter utama dan parameter pendukung. Parameter utama terdiri dari kontras warna permukaan datar serta bentuk dan pola objek. Parameter pendukung terdiri dari kemiringan sudut, intensitas cahaya dan jarak kamera pada saat tracking.

\section{METODE PENELITIAN}

Penelitian ini bertujuan untuk memanfaatkan metode markerless user defined target pada aplikasi augmented reality. Penelitian dilakukan dengan menggunakan berbagai benda dikehidupan seharihari. Sehingga dari hasil penelitian akan didapatkan objek atau benda apa saja yang dapat digunakan untuk mendukung aplikasi.

Aplikasi augmented reality sholat shubuh ini adalah sebuah aplikasi berbasis mobile yang terintegrasi dengan sistem operasi android. Aplikasi ini didesain khusus untuk satu orang saja (single user). User dapat menentukan sendiri objek atau penanda yang akan dijadikan marker pada saat menjalankan aplikasi. Deskripsi umum sistem dapat dilihat pada Gambar 1 .

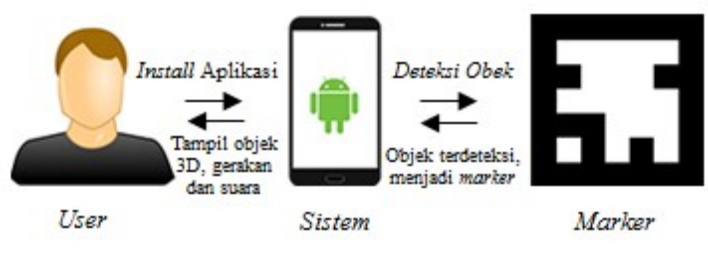

Gambar 1. Deskripsi Umum Sistem

Secara umum, alur sistem aplikasi augmented reality sholat shubuh adalah sebagai berikut: user meng-install aplikasi augmented reality sholat shubuh pada smartphone, user mengarahkan smartphone ke suatu objek, objek terdeteksi oleh smartphone dan menjadi marker, smartphone menampilkan objek 3 dimensi beserta gerakan dan suara dari objek yang sudah menjadi marker

\section{A. Indikator Variabel}

Indikator variabel dan skala pengukuran yang digunakan pada pengujian dibagi menjadi dua yaitu indikator kontras warna permukaan datar dan indikator bentuk objek. Indikator dan skala pengukuran kontras warna permukaan datar dapat dilihat pada Tabel 1 .

Tabel 1. Indikator Kontras Warna Permukaan Datar

\begin{tabular}{ccc}
$\begin{array}{c}\text { Indikator } \\
\text { Variabel }\end{array}$ & Sub Indikator Variabel & $\begin{array}{c}\text { Skala } \\
\text { Pengukuran }\end{array}$ \\
\hline & $\begin{array}{c}\text { 1. Permukaan hitam putih } \\
\text { kontras bagus }\end{array}$ & \\
$\begin{array}{c}\text { Kontras Warna } \\
\text { Permukaan } \\
\text { Objek }\end{array}$ & $\begin{array}{c}\text { 2. Permukaan berwarna } \\
\text { kontras bagus }\end{array}$ & Warna \\
& $\begin{array}{l}\text { 3. Permukaan hitam putih } \\
\text { kontras kurang bagus }\end{array}$ & \\
& 4. Permukaan berwarna &
\end{tabular}




\begin{tabular}{clc}
\hline $\begin{array}{c}\text { Indikator } \\
\text { Variabel }\end{array}$ & Sub Indikator Variabel & $\begin{array}{c}\text { Skala } \\
\text { Pengukuran }\end{array}$ \\
\hline \multirow{5}{*}{ Cahaya } & \multicolumn{1}{c}{ kontras kurang bagus } & \\
& $\begin{array}{l}\text { 1. Cahaya Lampu (Gelap) } \\
\text { 2. Cahaya Matahari } \\
\text { (Terang) }\end{array}$ & Lux \\
& 1. Jarak kamera $5 \mathrm{~cm}$ & \\
& $\begin{array}{l}\text { 2. Jarak kamera } 10 \mathrm{~cm} \\
\text { 3. Jarak kamera } 15 \mathrm{~cm}\end{array}$ & \\
& 4. Jarak kamera $20 \mathrm{~cm}$ & \\
Jarak & $\begin{array}{l}\text { 5. Jarak kamera } 25 \mathrm{~cm} \\
\text { 6. Jarak kamera } 30 \mathrm{~cm}\end{array}$ & \\
& 7. Jarak kamera $35 \mathrm{~cm}$ & \\
& 8. Jarak kamera $40 \mathrm{~cm}$ & \\
9. Jarak kamera $45 \mathrm{~cm}$ & \\
10. Jarak kamera $50 \mathrm{~cm}$ & \\
1. Sudut $45^{\circ}$ & Derajat \\
\hline
\end{tabular}

Indikator dan skala pengukuran bentuk dan pola objek dapat dilihat pada Tabel 2.

Tabel 2. Indikator Bentuk dan Pola Objek

\begin{tabular}{|c|c|c|}
\hline $\begin{array}{c}\text { Indikator } \\
\text { Variabel }\end{array}$ & Sub Indikator Variabel & $\begin{array}{c}\text { Skala } \\
\text { Pengukuran }\end{array}$ \\
\hline $\begin{array}{c}\text { Kontras Warna } \\
\text { Permukaan Objek }\end{array}$ & $\begin{array}{l}\text { 1. Permukaan hitam putih } \\
\text { kontras bagus } \\
\text { 2. Permukaan berwarna } \\
\text { kontras bagus } \\
\text { 3. Permukaan hitam putih } \\
\text { kontras kurang bagus } \\
\text { 4. Permukaan berwarna } \\
\text { kontras kurang bagus }\end{array}$ & Warna \\
\hline Cahaya & $\begin{array}{l}\text { 1. Cahaya Lampu (Gelap) } \\
\text { 2. Cahaya } \\
\text { (Terang) }\end{array}$ & $\operatorname{Lux}$ \\
\hline Jarak & $\begin{array}{l}\text { 1. Jarak kamera } 5 \mathrm{~cm} \\
\text { 2. Jarak kamera } 10 \mathrm{~cm} \\
\text { 3. Jarak kamera } 15 \mathrm{~cm} \\
\text { 4. Jarak kamera } 20 \mathrm{~cm} \\
\text { 5. Jarak kamera } 25 \mathrm{~cm} \\
\text { 6. Jarak kamera } 30 \mathrm{~cm} \\
\text { 7. Jarak kamera } 35 \mathrm{~cm} \\
\text { 8. Jarak kamera } 40 \mathrm{~cm} \\
\text { 9. Jarak kamera } 45 \mathrm{~cm} \\
\text { 10. Jarak kamera } 50 \\
\mathrm{~cm}\end{array}$ & $\mathrm{Cm}$ \\
\hline Sudut Tracking & $\begin{array}{l}\text { 1. Sudut } 45^{\circ} \\
\text { 2. Sudut } 90^{\circ}\end{array}$ & Derajat \\
\hline
\end{tabular}

\section{B. Teknik Penelitian}

Tahapan teknik pengujian secara lebih detail adalah sebagai berikut.

1. Menentukan kebutuhan pengujian.

2. Meng-install aplikasi augmented reality pada smartphone android.

3. Melakukan Pengujian dan pengambilan data dilakukan sesuai dengan indikator variabel yang ada dengan ketentuan, yaitu:

a. Pengujian dilakukan dengan memanfaatkan berbagai benda dikehidupan sehari-hari.

b. Apabila objek virtual 3 dimensi tidak muncul saat men-scan marker, maka akan diulang sebanyak tiga kali dengan marker yang sama.

4. Analisis data hasil pengujian.

5. Merumuskan simpulan

\section{HASIL DAN PEMBAHASAN}

Pengujian metode markerless user defined target ini difokuskan menggunakan benda di kehidupan sehari-hari yang dapat dijadikan marker. Pengujian dilakukan menggunakan sebuah smartphone android dengan spesifikasi sebagai berikut.

1. Merk : Lenovo P70-A

2. OS : Android Lollipop

3. RAM : $2 \mathrm{gb}$

4. Memory : $8 \mathrm{gb}$ internal dan 16 gb external

5. Kamera : 13 megapixel

Pengujian dilakukan di dua tempat yaitu di dalam kamar dan di teras rumah. Ilustrasi pengujian di dalam kamar dapat dilihat pada Gambar 2.



Gambar 2. Ilustrasi Pengujian di dalam Kamar Pribadi

Pengujian di kamar menggunakan sumber cahaya lampu redup dibawah standard SNI (SNI-03-61972000) [6].

Cahaya lampu tersebut menggunakan lampu fluorescent (neon) hemat energi dengan kekuatan 5 watt. Sumber cahaya berada tegak lurus dengan objek yang dijadikan marker dan posisi tracking menghadap ke Utara.

Ilustrasi pengujian di teras rumah dapat dilihat pada Gambar 3.

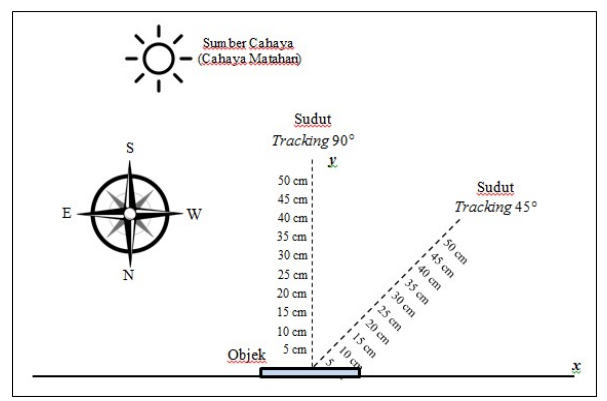

Gambar 3. Ilustrasi Pengujian di Teras Rumah

Pengujian di teras rumah menggunakan sumber cahaya matahari. Pengujian dilakukan pada jam 10:00 pagi hingga 12:00 siang dengan sumber cahaya yang 
tidak tegak lurus dengan objek yang dijadikan marker dan posisi tracking menghadap ke arah matahari.

Intensitas cahaya pada masing-masing tempat pengujian diukur menggunakan lux meter. Selain lux meter, alat lainnya yang digunakan pada pengujian ini adalah tripod, phone holder, meteran dan alat pengukur jarak dan sudut buatan. Fungsi dari alat-alat tersebut dapat dilihat pada Tabel 3.

\begin{tabular}{|c|c|c|}
\hline No & Nama Alat & Fungsi \\
\hline 1 & Lux meter & $\begin{array}{lcrr}\text { Untuk mengukur } & & \text { besarnya } \\
\text { intensitas } & \text { cahaya di } & \text { tempat } \\
\text { pengujian } & & & \end{array}$ \\
\hline 2 & Tripod & $\begin{array}{l}\text { Untuk menstabilkan jarak antara } \\
\text { smartphone dengan marker, } \\
\text { mengatur dan mengunci } \\
\text { kemiringan sudut smartphone }\end{array}$ \\
\hline 3 & Phone holder & $\begin{array}{l}\text { Untuk mengunci smartphone pada } \\
\text { tripod }\end{array}$ \\
\hline 4 & Meteran & $\begin{array}{l}\text { Untuk mengukur jarak smartphone } \\
\text { dengan marker }\end{array}$ \\
\hline 5 & $\begin{array}{l}\text { Alat pengukur } \\
\text { jarak dan sudut } \\
\text { buatan }\end{array}$ & $\begin{array}{l}\text { Untuk mengukur jarak dan sudut } \\
\text { smartphone dengan marker. }\end{array}$ \\
\hline
\end{tabular}

\section{A. Hasil Pengujian}

Hasil dari seluruh pengujian dibagi menjadi delapan bagian.

1. Pengujian Kontras Warna pada Cahaya Gelap dan Kemiringan Sudut $45^{\circ}$

Pengujian ini dilakukan pada permukaan datar kertas yang memiliki kontras warna pada intensitas cahaya gelap dengan kemiringan sudut $45^{\circ}$. Besarnya intensitas cahaya adalah 48 lux. Hasil pengujian dapat dilihat pada Tabel 4.

Berdasarkan Tabel 4 dapat disimpulkan bahwa seluruh permukaan yang digunakan pada pengujian dapat memunculkan objek 3 dimensi. Permukaan datar dengan kontras warna yang kurang bagus tidak dapat menampilkan objek 3 dimensi pada jarak $5 \mathrm{~cm}$ karena jarak yang terlalu dekat dan kontras yang kurang bagus membuat aplikasi tidak dapat membaca perbedaan kontras warna pada permukaan datar tersebut.

\section{Pengujian Kontras Warna pada Cahaya Gelap} dan Kemiringan Sudut $90^{\circ}$

Pengujian ini dilakukan pada permukaan datar kertas yang memiliki kontras warna pada intensitas cahaya gelap dengan kemiringan sudut $90^{\circ}$. Besarnya intensitas cahaya adalah 48 lux. Hasil pengujian dapat dilihat pada Tabel 5.

Berdasarkan Tabel 5 dapat disimpulkan seluruh permukaan yang digunakan pada pengujian dapat memunculkan objek 3 dimensi. Tingkat kemunculan objek pada jarak $5 \mathrm{~cm}$ menurun dibandingkan dengan percobaan 1 . Penurunan tingkat kemunculan objek pada jarak $5 \mathrm{~cm}$ tersebut dikarenakan pada saat tracking, sudut $90^{\circ}$ menghalangi sumber cahaya yang tegak lurus yang terpancar ke arah marker.

3. Pengujian Kontras Warna pada Cahaya Terang dan Kemiringan Sudut $45^{\circ}$

Pengujian ini dilakukan pada permukaan datar kertas yang memiliki kontras warna pada intensitas cahaya terang dengan kemiringan sudut $45^{\circ}$. Besarnya intensitas cahaya adalah 533 lux. Hasil pengujian dapat dilihat pada Tabel 6.

Berdasarkan Tabel 6 dapat disimpulkan bahwa seluruh permukaan datar yang digunakan pada pengujian dapat menampilkan objek 3 dimensi dengan jarak minimal $10 \mathrm{~cm}$. Objek 3 dimensi tidak dapat tampil pada jarak $5 \mathrm{~cm}$ dikarenakan jarak yang terlalu dekat dan cahaya yang terlalu terang membuat permukaan menjadi blur pada aplikasi sehingga aplikasi tidak dapat membaca perbedaan kontras warna yang ada.

Tabel 4. Hasil Pengujian 1

\begin{tabular}{|c|c|c|c|c|c|c|c|c|c|c|}
\hline \multirow{2}{*}{$\begin{array}{c}\text { Kontras Warna } \\
\text { Permukaan }\end{array}$} & \multicolumn{10}{|c|}{ Jarak (cm) } \\
\hline & 5 & 10 & 15 & 20 & 25 & 30 & 35 & 40 & 45 & $\mathbf{5 0}$ \\
\hline $\begin{array}{l}\text { Permukaan hitam } \\
\text { putih kontras bagus }\end{array}$ & Ya & Ya & Ya & Ya & Ya & Ya & Ya & Ya & Ya & Ya \\
\hline $\begin{array}{c}\text { Permukaan } \\
\text { berwarna kontras } \\
\text { bagus }\end{array}$ & Ya & Ya & Ya & Ya & Ya & Ya & Ya & Ya & Ya & Ya \\
\hline $\begin{array}{l}\text { Permukaan hitam } \\
\text { putih kontras } \\
\text { kurang bagus }\end{array}$ & Tidak & Ya & Ya & Ya & Ya & Ya & Ya & Ya & Ya & Ya \\
\hline $\begin{array}{l}\text { Permukaan } \\
\text { berwarna kontras } \\
\text { kurang bagus }\end{array}$ & Tidak & Ya & Ya & Ya & Ya & Ya & Ya & Ya & Ya & Ya \\
\hline
\end{tabular}


ISSN : 2085-3688; e-ISSN : 2460-0997

Analisis Pemanfaatan Metode Markerless User Defined Target Pada Augmented Reality Sholat Shubuh

Tabel 5. Hasil Pengujian 2

\begin{tabular}{|c|c|c|c|c|c|c|c|c|c|c|}
\hline \multirow{2}{*}{$\begin{array}{c}\text { Kontras Warna } \\
\text { Permukaan }\end{array}$} & \multicolumn{10}{|c|}{ Jarak (cm) } \\
\hline & 5 & 10 & 15 & 20 & 25 & 30 & 35 & 40 & 45 & 50 \\
\hline $\begin{array}{l}\text { Permukaan hitam } \\
\text { putih kontras bagus }\end{array}$ & Tidak & Ya & Ya & $\mathrm{Ya}$ & Ya & $\mathrm{Ya}$ & Ya & $\mathrm{Ya}$ & $\mathrm{Ya}$ & $\mathrm{Ya}$ \\
\hline $\begin{array}{c}\text { Permukaan } \\
\text { berwarna kontras } \\
\text { bagus }\end{array}$ & Tidak & Ya & $\mathrm{Ya}$ & Ya & Ya & $\mathrm{Ya}$ & Ya & $\mathrm{Ya}$ & Ya & $\mathrm{Ya}$ \\
\hline $\begin{array}{l}\text { Permukaan hitam } \\
\text { putih kontras } \\
\text { kurang bagus }\end{array}$ & Tidak & Ya & Ya & Ya & Ya & Ya & $\mathrm{Ya}$ & $\mathrm{Ya}$ & $\mathrm{Ya}$ & $\mathrm{Ya}$ \\
\hline $\begin{array}{l}\text { Permukaan } \\
\text { berwarna kontras } \\
\text { kurang bagus }\end{array}$ & Tidak & Ya & $\mathrm{Ya}$ & $\mathrm{Ya}$ & Ya & Ya & $\mathrm{Ya}$ & $\mathrm{Ya}$ & Ya & $\mathrm{Ya}$ \\
\hline
\end{tabular}

Tabel 6. Hasil Pengujian 3

\begin{tabular}{|c|c|c|c|c|c|c|c|c|c|c|}
\hline \multirow{2}{*}{$\begin{array}{c}\text { Kontras Warna } \\
\text { Permukaan }\end{array}$} & \multicolumn{10}{|c|}{ Jarak (cm) } \\
\hline & 5 & 10 & 15 & 20 & 25 & 30 & 35 & 40 & 45 & 50 \\
\hline $\begin{array}{l}\text { Permukaan hitam } \\
\text { putih kontras bagus }\end{array}$ & Tidak & $\mathrm{Ya}$ & Ya & $\mathrm{Ya}$ & $\mathrm{Ya}$ & $\mathrm{Ya}$ & $\mathrm{Ya}$ & $\mathrm{Ya}$ & $\mathrm{Ya}$ & $\mathrm{Ya}$ \\
\hline $\begin{array}{c}\text { Permukaan } \\
\text { berwarna kontras } \\
\text { bagus }\end{array}$ & Tidak & $\mathrm{Ya}$ & Ya & $\mathrm{Ya}$ & $\mathrm{Ya}$ & $\mathrm{Ya}$ & $\mathrm{Ya}$ & $\mathrm{Ya}$ & $\mathrm{Ya}$ & $\mathrm{Ya}$ \\
\hline $\begin{array}{c}\text { Permukaan hitam } \\
\text { putih kontras } \\
\text { kurang bagus }\end{array}$ & Tidak & $\mathrm{Ya}$ & Ya & $\mathrm{Ya}$ & $\mathrm{Ya}$ & $\mathrm{Ya}$ & $\mathrm{Ya}$ & $\mathrm{Ya}$ & $\mathrm{Ya}$ & $\mathrm{Ya}$ \\
\hline $\begin{array}{l}\text { Permukaan } \\
\text { berwarna kontras } \\
\text { kurang bagus }\end{array}$ & Tidak & $\mathrm{Ya}$ & Ya & $\mathrm{Ya}$ & $\mathrm{Ya}$ & $\mathrm{Ya}$ & Ya & $\mathrm{Ya}$ & Ya & $\mathrm{Ya}$ \\
\hline
\end{tabular}

4. Pengujian Kontras Warna pada Cahaya Terang dan Kemiringan Sudut $90^{\circ}$

Pengujian ini dilakukan pada permukaan datar kertas yang memiliki kontras warna pada intensitas cahaya terang dengan kemiringan sudut $90^{\circ}$. Besarnya intensitas cahaya adalah 535 lux. Hasil pengujian dapat dilihat pada Tabel 7.

Hasil pengujian pada Tabel 7 dapat disimpulkan bahwa seluruh permukaan yang digunakan pada pengujian dapat memunculkan objek 3 dimensi. Permukaan berwarna dengan kontras bagus tidak dapat menampilkan objek 3 dimensi pada jarak $5 \mathrm{~cm}$ karena warna yang terlalu banyak pada permukaan membuat permukaan menjadi semakin blur pada aplikasi.

5. Pengujian Bentuk Objek pada Cahaya Gelap dan Kemiringan Sudut $45^{\circ}$

Pengujian ini dilakukan pada bentuk objek yang memiliki sudut pada intensitas cahaya gelap dengan kemiringan sudut $45^{\circ}$. Besarnya intensitas cahaya adalah 54 lux. Hasil pengujian dapat dilihat pada Tabel 8.

Hasil pengujian pada Tabel 8 dapat disimpulkan bahwa benda yang tidak memiliki pola sulit untuk menampilkan objek 3 dimensi, karena aplikasi tidak dapat mengenali sudut dari benda tersebut khususnya benda berbentuk tabung. Benda berbentuk persegi yang memiliki pola dapat memunculkan objek 3 dimensi dengan jarak terdekat $5 \mathrm{~cm}$, karena benda tersebut memiliki banyak sudut dan pola yang dapat lebih mudah dikenali pada aplikasi.

\section{Pengujian Bentuk Objek pada Cahaya Gelap} dan Kemiringan Sudut $90^{\circ}$

Pengujian ini dilakukan pada benda yang memiliki sudut pada intensitas cahaya gelap dengan kemiringan sudut $90^{\circ}$. Besarnya intensitas cahaya adalah 52,4 lux. Hasil pengujian dapat dilihat pada Tabel 9.

Hasil pengujian pada Tabel 9 dapat disimpulkan bahwa aplikasi sangat sulit untuk dapat membaca benda yang tidak memiliki pola. Benda berbentuk tabung tanpa pola dapat menampilkan objek 3 dimensi pada jarak $50 \mathrm{~cm}$ karena aplikasi dapat membaca sudut ujung dari benda tersebut, bukan dari sudut pada badan tabung. Objek berbentuk persegi dapat menampilkan objek dari jarak $5 \mathrm{~cm}$ hingga jarak $50 \mathrm{~cm}$ karena benda tersebut memiliki banyak sudut dan pola yang lebih mudah dikenali aplikasi.

7. Pengujian Bentuk Objek pada Cahaya Terang dan Kemiringan Sudut $45^{\circ}$

Pengujian ini dilakukan pada benda yang memiliki sudut pada intensitas cahaya terang 
dengan kemiringan sudut $45^{\circ}$. Besarnya intensitas cahaya adalah 514 lux. Hasil pengujian dapat dilihat pada Tabel 10 .

Hasil pengujian pada Tabel 10 dapat disimpulkan bahwa seluruh benda yang digunakan pada pengujian dapat menampilkan objek 3 dimensi. Tingkat kemunculan objek 3 dimensi pada intensitas cahaya terang lebih baik dari pada intensitas cahaya kurang. Benda berbentuk tabung tanpa pola dapat menampilkan objek 3 dimensi pada jarak $25 \mathrm{~cm}$ karena aplikasi dapat membaca sudut ujung dari tabung tersebut, bukan dari sudut pada badan tabung. Benda berbentuk persegi yang memiliki banyak pola dapat menampilkan objek 3 dimensi pada jarak $5 \mathrm{~cm}$ hingga jarak $50 \mathrm{~cm}$.

8. Pengujian Bentuk Objek pada Cahaya Terang dan Kemiringan Sudut $90^{\circ}$
Pengujian ini dilakukan pada benda yang memiliki sudut pada intensitas cahaya terang dengan kemiringan sudut $90^{\circ}$. Besarnya intensitas cahaya adalah 525 lux. Hasil pengujian dapat dilihat pada Tabel 11.

Hasil pengujian pada Tabel 11 dapat disimpulkan bahwa seluruh benda yang digunakan pada pengujian dapat menampilkan objek 3 dimensi. Tingkat kemunculan objek 3 dimensi pada sudut $90^{\circ}$ lebih sedikit dibandingkan dengan sudut $45^{\circ}$ terutama pada benda berbentuk tabung. Benda berbentuk tabung tanpa pola dapat menampilkan objek 3 dimensi pada jarak $30 \mathrm{~cm}$ karena aplikasi dapat membaca sudut ujung dari tabung tersebut, bukan dari sudut pada badan tabung. Benda yang memiliki banyak pola seperti persegi dapat menampilkan objek 3 dimensi pada jarak $5 \mathrm{~cm}$ hingga $50 \mathrm{~cm}$.

Tabel 7. Hasil Pengujian 4

\begin{tabular}{|c|c|c|c|c|c|c|c|c|c|c|}
\hline \multirow{2}{*}{$\begin{array}{c}\text { Kontras Warna } \\
\text { Permukaan }\end{array}$} & \multicolumn{10}{|c|}{ Jarak (cm) } \\
\hline & 5 & 10 & 15 & 20 & 25 & 30 & 35 & 40 & 45 & 50 \\
\hline $\begin{array}{l}\text { Permukaan hitam } \\
\text { putih kontras bagus }\end{array}$ & $\mathrm{Ya}$ & Ya & $\mathrm{Ya}$ & $\mathrm{Ya}$ & $\mathrm{Ya}$ & $\mathrm{Ya}$ & $\mathrm{Ya}$ & Ya & $\mathrm{Ya}$ & $\mathrm{Ya}$ \\
\hline $\begin{array}{c}\text { Permukaan } \\
\text { berwarna kontras } \\
\text { bagus }\end{array}$ & Tidak & $\mathrm{Ya}$ & $\mathrm{Ya}$ & $\mathrm{Ya}$ & $\mathrm{Ya}$ & $\mathrm{Ya}$ & $\mathrm{Ya}$ & Ya & $\mathrm{Ya}$ & $\mathrm{Ya}$ \\
\hline $\begin{array}{l}\text { Permukaan hitam } \\
\text { putih kontras } \\
\text { kurang bagus }\end{array}$ & Tidak & Ya & $\mathrm{Ya}$ & $\mathrm{Ya}$ & $\mathrm{Ya}$ & $\mathrm{Ya}$ & $\mathrm{Ya}$ & $\mathrm{Ya}$ & $\mathrm{Ya}$ & $\mathrm{Ya}$ \\
\hline $\begin{array}{l}\text { Permukaan } \\
\text { berwarna kontras } \\
\text { kurang bagus }\end{array}$ & Tidak & $\mathrm{Ya}$ & $\mathrm{Ya}$ & $\mathrm{Ya}$ & $\mathrm{Ya}$ & $\mathrm{Ya}$ & $\mathrm{Ya}$ & Ya & $\mathrm{Ya}$ & $\mathrm{Ya}$ \\
\hline
\end{tabular}

Tabel 8. Hasil Pengujian 5

\begin{tabular}{|c|c|c|c|c|c|c|c|c|c|c|}
\hline \multirow{2}{*}{ Bentuk Objek } & \multicolumn{10}{|c|}{ Jarak (cm) } \\
\hline & 5 & 10 & 15 & 20 & 25 & 30 & 35 & 40 & 45 & 50 \\
\hline $\begin{array}{l}\text { Objek berbentuk } \\
\text { tabung tanpa pola }\end{array}$ & Tidak & Tidak & Tidak & Tidak & Tidak & Tidak & Tidak & Tidak & Tidak & Tidak \\
\hline $\begin{array}{l}\text { Objek berbentuk } \\
\text { tabung dengan pola }\end{array}$ & Tidak & Ya & Ya & Ya & Ya & Ya & Ya & Ya & Ya & Ya \\
\hline $\begin{array}{l}\text { Objek berbentuk } \\
\text { balok tanpa pola }\end{array}$ & Tidak & Tidak & Tidak & Tidak & Ya & Ya & $\mathrm{Ya}$ & Ya & Ya & Ya \\
\hline $\begin{array}{l}\text { Objek berbentuk } \\
\text { persegi dengan pola }\end{array}$ & Ya & Ya & Ya & Ya & Ya & Ya & Ya & Ya & Ya & Ya \\
\hline
\end{tabular}

Tabel 9. Hasil Pengujian 6

\begin{tabular}{|c|c|c|c|c|c|c|c|c|c|c|}
\hline \multirow{2}{*}{ Bentuk Objek } & \multicolumn{10}{|c|}{ Jarak (cm) } \\
\hline & 5 & 10 & 15 & 20 & 25 & 30 & 35 & 40 & 45 & 50 \\
\hline $\begin{array}{l}\text { Objek berbentuk } \\
\text { tabung tanpa pola }\end{array}$ & Tidak & Tidak & Tidak & Tidak & Tidak & Tidak & Tidak & Tidak & Tidak & $\mathrm{Ya}$ \\
\hline $\begin{array}{l}\text { Objek berbentuk } \\
\text { tabung dengan pola }\end{array}$ & Tidak & Tidak & Tidak & $\mathrm{Ya}$ & $\mathrm{Ya}$ & $\mathrm{Ya}$ & $\mathrm{Ya}$ & $\mathrm{Ya}$ & $\mathrm{Ya}$ & $\mathrm{Ya}$ \\
\hline $\begin{array}{l}\text { Objek berbentuk } \\
\text { balok tanpa pola }\end{array}$ & Tidak & Tidak & Tidak & Tidak & Tidak & Tidak & Tidak & Tidak & Tidak & Tidak \\
\hline $\begin{array}{l}\text { Objek berbentuk } \\
\text { persegi dengan pola }\end{array}$ & $\mathrm{Ya}$ & $\mathrm{Ya}$ & $\mathrm{Ya}$ & $\mathrm{Ya}$ & $\mathrm{Ya}$ & $\mathrm{Ya}$ & $\mathrm{Ya}$ & $\mathrm{Ya}$ & $\mathrm{Ya}$ & $\mathrm{Ya}$ \\
\hline
\end{tabular}


ISSN : 2085-3688; e-ISSN : 2460-0997

Analisis Pemanfaatan Metode Markerless User Defined Target Pada Augmented Reality Sholat Shubuh

\begin{tabular}{|c|c|c|c|c|c|c|c|c|c|c|}
\hline \multicolumn{11}{|c|}{ Tabel 10. Hasil Pengujian 7} \\
\hline \multirow{2}{*}{ Bentuk Objek } & \multicolumn{10}{|c|}{ Jarak (cm) } \\
\hline & 5 & 10 & 15 & 20 & 25 & 30 & 35 & 40 & 45 & 50 \\
\hline $\begin{array}{l}\text { Objek berbentuk } \\
\text { tabung tanpa pola }\end{array}$ & Tidak & Tidak & Tidak & Tidak & $\mathrm{Ya}$ & $\mathrm{Ya}$ & $\mathrm{Ya}$ & $\mathrm{Ya}$ & $\mathrm{Ya}$ & Ya \\
\hline $\begin{array}{l}\text { Objek berbentuk } \\
\text { tabung dengan pola }\end{array}$ & Tidak & Tidak & Tidak & $\mathrm{Ya}$ & Ya & Ya & $\mathrm{Ya}$ & $\mathrm{Ya}$ & $\mathrm{Ya}$ & $\mathrm{Ya}$ \\
\hline $\begin{array}{l}\text { Objek berbentuk } \\
\text { balok tanpa pola }\end{array}$ & Tidak & Tidak & $\mathrm{Ya}$ & Ya & $\mathrm{Ya}$ & Ya & $\mathrm{Ya}$ & $\mathrm{Ya}$ & Ya & Ya \\
\hline $\begin{array}{l}\text { Objek berbentuk } \\
\text { persegi dengan pola }\end{array}$ & $\mathrm{Ya}$ & $\mathrm{Ya}$ & $\mathrm{Ya}$ & $\mathrm{Ya}$ & $\mathrm{Ya}$ & Ya & $\mathrm{Ya}$ & $\mathrm{Ya}$ & Ya & Ya \\
\hline
\end{tabular}

Tabel 11. Hasil Pengujian 8

\begin{tabular}{|c|c|c|c|c|c|c|c|c|c|c|}
\hline \multirow{2}{*}{ Bentuk Objek } & \multicolumn{10}{|c|}{ Jarak (cm) } \\
\hline & 5 & 10 & 15 & 20 & 25 & 30 & 35 & 40 & 45 & 50 \\
\hline $\begin{array}{l}\text { Objek berbentuk } \\
\text { tabung tanpa pola }\end{array}$ & Tidak & Tidak & Tidak & Tidak & Tidak & $\mathrm{Ya}$ & $\mathrm{Ya}$ & $\mathrm{Ya}$ & $\mathrm{Ya}$ & $\mathrm{Ya}$ \\
\hline $\begin{array}{l}\text { Objek berbentuk } \\
\text { tabung dengan pola }\end{array}$ & Tidak & Tidak & Tidak & $\mathrm{Ya}$ & $\mathrm{Ya}$ & $\mathrm{Ya}$ & $\mathrm{Ya}$ & $\mathrm{Ya}$ & $\mathrm{Ya}$ & Ya \\
\hline $\begin{array}{l}\text { Objek berbentuk } \\
\text { balok tanpa pola }\end{array}$ & Tidak & Tidak & Tidak & Tidak & $\mathrm{Ya}$ & $\mathrm{Ya}$ & $\mathrm{Ya}$ & $\mathrm{Ya}$ & $\mathrm{Ya}$ & Ya \\
\hline $\begin{array}{l}\text { Objek berbentuk } \\
\text { persegi dengan pola }\end{array}$ & $\mathrm{Ya}$ & $\mathrm{Ya}$ & $\mathrm{Ya}$ & $\mathrm{Ya}$ & $\mathrm{Ya}$ & $\mathrm{Ya}$ & $\mathrm{Ya}$ & $\mathrm{Ya}$ & $\mathrm{Ya}$ & Ya \\
\hline
\end{tabular}

Berdasarkan keseluruhan pengujian yang telah dilakukan dapat disimpulkan bahwa tingkat kemunculan objek 3 dimensi pada kontras permukaan datar lebih baik dibandingkan dengan bentuk objek. Permukaan datar dengan kontras bagus dapat menampilkan objek 3 dimensi pada jarak terdekat $5 \mathrm{~cm}$ dengan menggunakan cahaya gelap dan kemiringan sudut $45^{\circ}$, sedangkan jarak terdekat untuk menampilkan objek 3 dimensi pada permukaan datar dengan kontras kurang bagus adalah $10 \mathrm{~cm}$.

\section{PENUTUP}

\section{A. Kesimpulan}

Kesimpulan yang dapat diambil dari pengujian tentang pemanfaatan metode markerless user defined target pada aplikasi augmented reality ini adalah sebagai beriku.

1. Kondisi terbaik untuk menampilkan objek 3 dimensi pada permukaan datar kertas adalah menggunakan permukaan dengan kontras bagus, sudut tracking $45^{\circ}$, jarak $15 \mathrm{~cm}$ dan menggunakan sumber cahaya terang yang tidak tegak lurus dengan permukaan datar tersebut.

2. Kondisi terbaik untuk menampilkan objek 3 dimensi pada bentuk benda adalah objek yang memiliki pola, menggunakan sudut tracking $45^{\circ}$, jarak $25 \mathrm{~cm}$ dengan sumber cahaya terang yang tidak tegak lurus dengan objek tersebut.

\section{B. Saran}

Berdasarkan pengujian dan kesimpulan yang telah didapat, muncul beberapa kritik dan saran yang dapat diperhatikan untuk pengembangan penelitian ini di masa yang akan datang. Beberapa kritik dan saran tersebut diantaranya.

1. Penelitian kontras warna pada permukaan datar dengan permukaan bahan lain seperti permukaan kain, permukaan keramik dan permukaan kaca.

2. Penelitian lebih fokus tentang besarnya sudut minimum suatu benda yang dapat dikenali oleh aplikasi untuk dapat menampilkan objek 3 dimensi.

3. Diharapkan kedepannya banyak pengembang yang menggunakan metode markerless user defined target pada aplikasi augmented reality yang diciptakan.

\section{DAFTAR PUSTAKA}

[1] Kipper, Gregory dan Rampolla, Joseph. 2013. Augmented Reality: An Emerging Technologies Guide to AR. Elsevier Inc.: Amsterdam.

[2] Permata Sari, Irma. dkk. 2014. Evaluasi Kemampuan Sistem Pendeteksian Objek Augmented Reality secara Cloud Recognition. Jurusan Teknik Elektro dan Teknik Informasi Universitas Gadjah Mada. Yogyakarta.

[3] Rizki, Yoze. 2007. Markerless Augmented Reality pada Perangkat Android. Jurusan Teknik Elektro Fakultas Teknologi Industri ITS. Surabaya.

[4] User Defined Targets. https://developer.vuforia.com/library/articles/Training/ User-Defined-Targets-Guide.

[5] Al-Qarny, Samir bin Riziq, Muhammad. 2007. Sulitkah Shalat Subuh Tepat Waktu? (diterjemahkan oleh Imtihan Asy Syafi'i). Media Zikir: Solo.

[6] Badan Standardisasi Nasional. 2000. Konservasi Energi pada Sistem Pencahayaan. SNI 03-6197-2000. 